\section{Praktyki kontrfaktualne w narracjach naukowych i fikcjonalnych}

\author{
Małgorzata Sugiera
}

TEKSTY DRUGIE 2017, NR 1, S. 176-186

DOI: $10.18318 /$ td.2017.1.14
Niniejszy tekst powstał w ramach projektu badawczego Narodowego Centrum Nauki „Performanse pamięci: strategie testymonialne, rekonstrukcyjne i kontrfaktyczne w literaturze i sztukach performatywnych XXiXXI wieku" (UMO-2014/15/G/ $\left.\mathrm{HS}_{2} / 04803\right)$.
W tytułach wielu anglojęzycznych prac z pogranicza historii i fikcji pojawia się spójnik „if”, który zgodnie z regułami gramatyki rozpoczyna zdanie podrzędne i sygnalizuje możliwość, niespełniony warunek realizacji tego, o czym mowa w zdaniu głównym¹. Autorzy tych prac, w większości poważni i poważani historycy, wolne chwile często poświęcali na zabawy w spekulacje, chwaląc się zarazem swoimi pisarskimi umiejętnościami. U schyłku XIX wieku francuski filozof Charles Renouvier takim potencjalnym wersjom historii nadał nazwę „uchronie”. Bardziej współcześnie mówi się raczej o historiach alternatywnych, historii wirtualnej czy narracji o przeszłości

1 Zob. np. What If? The World's Foremost Military Historians Imagine What Might Have Been, ed. by R. Cowley, Putnam, New York 1999; More What If?: Eminent Historians Imagine What Might Have Been, ed. by R. Cowley, Putnam, New York 2001; What If? America. Eminent Historians Imagine What Might Have Been, ed. by R. Cowley, Putnam, New York 2003; What Might Have Been?: Leading Historians on Twelve "What Ifs" of History: Imaginary History from Twelve Leading Historians, ed. by A. Roberts, Weidenfeld \& Nicolson, London 2004; J. Bulhof What if? Modality and History, "History and Theory" 1999 No. 2, s. 145-168; J. Black What If? Counterfactualism and the Problem of History, Social Affairs Unit, London 2008.

\section{Małgorzata Sugiera}

- prof. dr hab., kierownik Katedry Performatyki UJ. W roku 2015/2016 prowadziła badania W IRC "Interweaving Performance Cultures" na FU w Berlinie. Wydała 12 monografii, ostatnio Nieludzie. Donosy ze sztucznych natur (2015) oraz z Mateuszem Borowskim Sztuczne natury. Performanse technonauki i sztuki (2016). Zajmuje się także tłumaczeniem prac naukowych i sztuk teatralnych. 
w trybie warunkowym, ostatnio coraz częściej o historii kontrfaktualnej czy - szerzej - kontrfaktualności². Jedną z konsekwencji wzrostu zainteresowania historiami alternatywnymi było coraz wyraźniejsze podważenie granicy między powieścią historyczną a nurtem fantastyki naukowej. W Archeologiach przyszłości Fredric Jameson stara się jeszcze te granice zachować, stawiając tezę, że powieść historyczna musiała ustąpić miejsca fantastycznonaukowej’ . Nie uwzględnia wszakże tego, jak często ta ostatnia posługuje się chwytem historycznej relacji o wydarzeniach rozgrywających się w przyszłości, jak dzieje się choćby w The Last Man Mary Shelley czy The Last and First Men Olafa Stapledona. Nie mówiąc nawet o tym, że określenie „zaginiony świat", często używane w odniesieniu do historii alternatywnych, pojawiło się w tytule powieści Arthura Conan Doyle'a, należącej do fantastycznonaukowego cyklu utworów o przygodach ekscentrycznego profesora Challengera. U progu tego stulecia zaczęła się zaś wyłaniać nowa dyscyplina akademicka, która zajmuje się nie tylko spekulacjami badaczy na temat przeszłości, ale nade wszystko retoryką przedstawień przeszłości w jej przyjętych i domniemanych wersjach w naukach humanistycznych, a także metodologią ich badań. Tym samym spekulacje na temat alternatywnych wersji historii, zwykle zmieniających również współczesność i możliwe oblicza przyszłości, ze sfery rozrywki przeniosły się na poziom refleksji nad sensem i sposobem uprawiania zarówno historii i np. historii literatury, jak i produkcji wiedzy historycznej w kulturze popularnej ${ }^{4}$.

Jak można się spodziewać, w większości przypadków da się dość łatwo odróżnić snute przez profesjonalnych historyków alternatywne wizje Europy w drugiej połowie XX wieku w chwili, gdyby wojska alianckie nie wygrały z Hitlerem, od takiego choćby ich ujęcia, jakie w powieści Vaterland zaproponował Robert Harris, nawet jeśli część przedstawionych zdarzeń oparł on na często cytowanych in extenso dokumentach archiwalnych ${ }^{5}$. Dlatego kilka lat temu Lubomír Doležel w Possible

2 Dobre wprowadzenie w tę problematykę oferuje wstęp do bibliografii na prowadzonej przez Roberta B. Schmunka stronie internetowej Uchronia: The Alternate History List, która powstała W 1991 roku jako grupa tematyczna jeszcze na Usernet, a w tej chwili obejmuje ponad 3200 powieści, opowiadań, esejów i innych materiałów drukowanych, podejmujących temat "co by było gdyby" w historii, por. http:www.uchronia.net (23.08.2016).

3 Por. F. Jameson Archeologie przyszłości. Pragnienie zwane utopiq i inne fantazje naukowe [2005], przeł. M. Płaza, M. Frankiewicz, A. Miszk, Wydawnictwo UJ, Kraków 2011.

4 Por. np. A. Landsberg Engaging the Past. Mass Culture and the Production of Historical Knowledge, Columbia University Press, New York 2015.

5 R. Harris Vaterland [1992], przeł. A. Szulc, Książnica, Poznań 2008. W ostatnich latach wiele powieści proponujących alternatywne wersje historii ukazało się w serii "Zwrotnice Czasu" Narodowego Centrum Kultury. 
Worlds of Fiction and History bez większego trudu wykazał istotne różnice między spekulacjami historyków a możliwymi światami, które powołują do istnienia posługujący się realistyczną konwencją powieściopisarze, nawet po skrupulatnych studiach nad wybranym tematem ${ }^{6}$. Choć Doležel przekonująco udowodnił, że oboma światami rządzą odmienne prawa retoryki i wywoływania efektu realności, nie przesądził wcale o większej prawdziwości jednego z nich. Nauka i literatura w jego ujęciu pozostały odrębnymi dziedzinami o różnych zasadach referencyjności i wiarygodności ${ }^{7}$. Nie zmienia to jednak faktu, że w ostatnich latach mnożą się eksperymenty na skrzyżowaniu różnych nauk humanistycznych i literackiej fikcji. W tym miejscu przywołam jedynie trzy tak wybrane przykłady, by pochodziły z odmiennych dyscyplin.

Jednym z pierwszych, którzy ujawnili gest fikcjonalizacji jako ramy prowadzonych rozważań naukowych, był Manuel DeLanda w pracy War in the Age of the Intelligent Machines, wydanej na początku ostatniej dekady ubiegłego wieku ${ }^{8}$. Wychodząc z założenia rodem z science fiction, że „robot historyk musiałby uprawiać inną historiografię niż jego ludzki odpowiednik" (s. 3), DeLanda demonstracyjnie przyjął punkt widzenia inteligentnej maszyny, rekonstruującej historię sobie podobnych, w której czas, przebieg i wyniki zarówno wojen, jak i bitew w ograniczonym stopniu zależą od ludzkiej sprawczości. Ważką rolę odgrywa w nich natomiast złożony system technologii militarnych i przemysłowych, od niedawna również broni cyfrowych, poczynając od wyćwiczonych technik posługiwania się ciałem przez żołnierzy, przez wykorzystywane diagramy i mapy, stosowane metody kalibracji broni, aprowizacji i komunikacji, aż po regulacje prawne i obowiązujące protokoły dyplomatyczne. Dynamiczne i historycznie zmienne asamblaże ludzi i nieludzi sprawiły również, że antropolog Anna Lowenhaupt Tsing w The Mushroom at the End of the World odeszła od przyjętej koncepcji prac naukowych i właściwego im efektu wiarygodności. Podczas gdy DeLanda jedynie wybrał odmienną perspektywę, nadal zaś zachował styl i retorykę typowe dla argumentacji historyków, Tsing poszła o krok dalej. Uwzględniła przy tym specyfikę przedmiotu badań, czyli zmienne

6 L. Doležel Possible Worlds in Fiction and History. The Postmodern Stage, John Hopkins University Press, Baltimore 2010.

7 Na podobnej zasadzie alternatywne wersje przeszłości, proponowane przez historyków, jako niemające wymaganej wiarygodności (plausibility) ocenia np. R.J. Evans w Altered Pasts. Counterfactuals in History, Little, Brown, London 2014.

8 M. DeLanda War in the Age of Intelligent Machines, Swerve, New York 1991.

9 A. Lowenhaupt Tsing The Mushroom at the End of the World: On the Possibility of Life in Capitalist Ruins, Princeton University Press, Princeton 2015. 
ekosystemy, w których skład w różnych geograficznych lokalizacjach wchodzi grzyb matsutake, preferujący zdegradowane biotopy. Śledząc powodowane przez matsutake akty translacji w odmiennych ekonomicznych, społecznych i politycznych przestrzeniach, Tsing wyodrębniła swoisty dla nich typ asamblażu polifonicznego, który różni się zarówno od dyskursywnych formacji Michela Foucaulta, jak i od interakcyjnych, intencjonalnych sieci Brunona Latoura. W efekcie musiała odnotować istotną dysproporcję między tematem a formą planowanej monografii. Z jednej strony miała otwarte, bezskalowe, symbiopojetyczne i najczęściej przypadkowe, chwilowe spotkania rozmaitych czasowości i trajektorii, z drugiej zamknięty, prowadzony linearnie, kumulacyjny i schematyczny wywód naukowy. Dlatego zdecydowała się odejść od obowiązujących zasad i zamiast klasycznej monografii przygotować podobny asamblaż polifoniczny, z pełniącymi wręcz poetycką funkcję fotografiami. Jak widać, sytuacyjność badań etnograficznych, prowadzonych przez wielu antropologów, znalazła w jej przypadku bezpośrednie odzwierciedlenie w nowej i wyraźnie usytuowanej retoryce naukowego dyskursu.

Nieco inne, i dlatego warte przywołania, rozwiązanie dla dylematu dysproporcji między przedmiotem badań a retoryką prezentacji ich wyników zaproponowała brytyjska dziennikarka Kate Summerscale, w wyrafinowany sposób posługując się metodami analizy teoretyków kultury, w książce The Suspicions of Mr. Whicher, należącej do nurtu „crime nonfiction"10. Wybrała w niej najbardziej rozpoznawalne elementy wiktoriańskiej powieści detektywistycznej, żeby przedstawić wyniki skrupulatnych badań w archiwach i bibliotekach na dwa ściśle ze sobą powiązane tematy. Po pierwsze, podjęła wątek jednego z prototypów Sherlocka Holmesa, czyli Jonathana „Jacka” Whichera, który znalazł się w pierwszej ósemce detektywów londyńskiego Scotland Yardu, zaś w 1860 roku prowadził sprawę głośnego w Wielkiej Brytanii morderstwa trzyletniego dziecka na Road Hill w prowincjonalnym Wiltshire. Po drugie zaś, zainteresowały ją wczesne opowiadania i powieści kryminalne, które m.in. wydała na świat "gorączka detektywistyczna" pod wpływem nagłośnionego śledztwa i kolejnych rozpraw sądowych. Proponowana przez Summerscale rekonstrukcja śledztwa Whichera to zamierzona hybryda różnych typów piśmiennictwa, na pograniczu powieści (wszystkie wypowiedzi postaci pochodzą z protokołów rozpraw sądowych), studium historycznego i historycznoliterackiej rozprawki. Zarówno ten, jak i pozostałe dwa przykłady dobitnie pokazują, że uwzględnienie alternatywnych wersji przeszłości przez profesjonalnych history-

10 K. Summerscale The Suspicions of Mr. Whicher. The Shocking Murder and the Undoing of a Great Victorian Detective, Walker \& Company 2008; Podejrzenia pana Whichera. Morderstwo w domu na Road Hill, przeł. M. Jaszczurowska, W.A.B., Warszawa 2010. 
ków przynosi dziś odkrywcze eksperymenty nie tylko na ich własnym polu badań, nazywane fikcją dokumentalną (dokufiction) lub mockumentem (mockumentary). Jak się jednak wydaje, kontrfaktualność ma do spełnienia jeszcze inne żywotne funkcje.

Wartość kontrfaktualności jako narzędzia rozumienia historii, „demonstrującego udział w niej przypadku, a tym samym ludzkiej sprawczości" (s. ix ${ }^{11}$, najlepiej bodaj pokazał Jeremy Black, profesor historii na Uniwersytecie w Exeter, w niedawnej pracy Other Pasts, Different Presents, Alternative Futures. Zwrócił w niej uwagę przede wszystkim na to, jak trudno znaleźć adekwatną odpowiedź na podstawowe dla naszych prób rozumienia minionego czasu pytanie „dlaczego”, nie rozważając możliwych wersji przeszłych wydarzeń. Black wyjaśnia: „Istota kontrfaktualności sprowadza się do tego, że pozwala wrócić do specyficznej sytuacji niepewności, w której rozważano kiedyś alternatywne decyzje, by następnie tylko jedną z nich wybrać i zrealizować" (s. 2). Taki eksperyment myślowy pozwala wziąć pod uwagę nie tylko związki przyczynowo-skutkowe między serią sytuacji, lecz także uwzględnić różnorakie motywy, zamiary i aktualne moce sprawcze uwikłanych w nie aktorów; ludzkich aktorów teatru historii w tradycyjnym rozumieniu. Dlatego zarówno wcześniejsze zabawy profesorów historii, jak i rozwijająca się dziś historia kontrfaktualna koncentrują uwagę na wojnach i bitwach, proponując spekulacje na temat ich alternatywnych przebiegów i wyników. Jak podkreśla Black, w tych uznawanych za przełomowe momentach w dziejach znakomicie widać pierwszoplanową rolę ludzkiej sprawczości. Tymczasem, jeśli wierzyć sugestiom DeLandy, właśnie wtedy ludzka sprawczość usuwa się zdecydowanie na drugi plan, zaś profesjonalni historycy wciąż jeszcze zbyt małą wagę przykładają do innych biotycznych i abiotycznych aktorów, obdarzonych wcale nie mniejszą sprawczością. Co innego wszakże interesuje mnie w tym miejscu bardziej, a mianowicie - mniej istotne dla Blacka - konsekwencje kontrfaktyczności dla akademickiej historii oraz przyjętej w jej ramach koncepcji faktów.

Black nie mógł oczywiście pominąć opinii tych znanych historyków, którzy nadal ostro potępiają prace naukowe poświęcone dywagacjom na temat tego, co nigdy się nie zdarzyło, gdyż widzą w nich karygodny relatywizm lub wpływy konkretnych opcji politycznych, sprzeczne z ideą obiektywizmu nauki. Trzeźwo polemizując z ich argumentami, podkreśla on w pewnym momencie, że typowe dla kontrfaktualności spekulacje przeprowadza w gruncie rzeczy każdy szanujący się historyk. Problem oczywiście w tym, że stanowią one jedynie wstępny etap badań i typowych dla nich spekulacji, a następnie nie wchodzą do ostatecznych wersji

11 J. Black Other Pasts, Different Presents, Alternative Futures, Indiana University Press, Bloomington-Indianapolis 2015. 
wykładów i publikacji. Nikt bodaj nie zdefiniował mechanizmu obiektywizacji tak produkowanej wiedzy historycznej lepiej niż niemiecki historyk Johann Christoph Gatterer w 1767 roku. W tekście Vom historischen Plan und der darauf sich gründenden Zusammenfügung der Erzählungen, programowym dla powstającej wtedy dyscypliny akademickiej, napisał on wprost: „Zdarzenia, które nie należą do systemu, dla piszącego historię przestają po prostu od tej chwili być zdarzeniami” ${ }^{\prime 2}$. Innymi słowy, przyjęta forma narracji (system) zaczęła decydować o tym, które z udokumentowanych zdarzeń mogły stać się zdarzeniami rzeczywistymi, nabywając rangi faktów historycznych. Pozostałe najzwyczajniej znikały z pola widzenia zarówno piszącego historię, jak i historii jako dyscypliny naukowej. To prawda, Hayden White już od połowy lat 70. XX wieku zwraca uwagę na decydującą rolę narracji oraz właściwej jej logiki przyczyn i skutków w ustanawianiu tego, co znajdzie się następnie w kanonie prac historycznych i tym samym w pamięci zbiorowej ${ }^{13}$. Robi to, nadal jednak uprawiając przyjętą formę dyskursu naukowego. Tymczasem zwolennicy kontrfaktyczności coraz aktywniej postulują i - jak dowodzą przywołane już przykłady - realizują własne postulaty, włączając w ten dyskurs to, co dotąd pozostawało na marginesie ustanawiającego fakty historyczne systemu, by posłużyć się określeniem Gatterera. Zawraca to po części historię jako dyscyplinę naukową do punktu wyjścia, ujawniając zarazem jej systemowy charakter i warunkowaną nim sytuacyjność, źródłowy gest usuwania w cień tego, co z jakichś względów nie zdołało się zmieścić w ramach pożądanych narracji i typowych dla nich sensotwórczych zabiegów porządkujących.

Nieodwracalna i nadająca sens następującym po sobie sytuacjom logika przyczyny i skutku to podstawowy zabieg zarówno w narracjach fikcjonalnych, jak i prowadzonych w naukach humanistycznych, co pozwala m.in. na powstawanie analizowanych wcześniej utworów z ich pogranicza. Jednak mniej więcej w tym samym czasie, kiedy funkcję zabiegów retorycznych w historiografii zaczął ujawniać i analizować Hayden White, zasady działania podobnego mechanizmu w naukach ścisłych pokazali w etnograficznym studium praktyk eksperymentalnych Laboratory Life Bruno Latour i Steve Woolgar ${ }^{14}$. Choć badacze w laboratoriach mają do czynienia z konkretnymi zjawiskami fizycznymi i chemicznymi, to jednak podstawę

12 Cyt. za: R. Koselleck, H. Günther Geschichte, w: Geschichtliche Grundbegriffe. Historisches Lexikon zur politisch-sozialen Sprache in Deutschland, Hrgs. von O. Brunner, W. Conze, R. Koselleck, Klett-Cotta, Stuttgart 1975, t. 2, s. 593-717, tu s. 663.

13 Por. choćby: H. White Poetyka pisarstwa historycznego, red. E. Domańska, M. Wilczyński, Universitas, Kraków 2000 (wyd. 2 popr. i uzup. 2010). 
wytwarzanych przez nich faktów naukowych stanowi dyskurs pisany i typowa dla niego retoryka. W podtytule Laboratory Life pojawia się jeszcze formuła "the construction of scientific facts". Ale jednak - jak pokazały późniejsze prace Latoura, a zwłaszcza wydana niedawno An Inquiry into Modes of Existence: An Anthropology of the Moderns ${ }^{15}$ - od początku chodziło nie tyle o arbitralne konstrukcje, ile o proces negocjacji między ludźmi a biotycznymi i abiotycznymi nieludźmi, obdarzonymi podobną sprawczością. Dotyczyło to zresztą nie tylko prowadzonych eksperymentów, ale także etapu włączania ich rezultatów w obowiązujący dyskurs danej nauki z typową dla niego krążącą referencją ${ }^{16}$. To właśnie łańcuch wzajemnych odniesień między kolejnymi poziomami uogólnień gwarantuje skalowalność i spójność takiego dyskursu, tworząc tym samym swoiste dla niego warunki fortunności, tyleż aktów mowy, ile modusu istnień. Pozwala to nie tylko odróżnić prawdę od fałszu, lecz także ustanowić jej obiektywność i uniwersalność.

Nie przez przypadek, jak sądzę, określenie „negocjacje”, a także przekonanie, że świat nie jest wcale surowym materiałem, oczekującym na nadanie mu sensu w ramach ludzkich systemów porządkujących, pojawiło się w podobnym kontekście dekadę później, pod koniec lat 8o. XX wieku, w ważnym artykule Situated Knowledges Donny Haraway ${ }^{17}$. Podjęła ona w nim kwestię relacji między (obiektywnymi) naukami i oskarżanymi o ideologiczny punkt widzenia teoriami feministycznymi, podkreślając zalety perspektywy lokalnej, zależnej od kontekstu (situated), a więc zamierzenie częściowej i historycznie zmiennej. Haraway postulowała też konieczność istnienia wielu różnych wiedz praktycznych i praktykowanych (choć uzus nie przewiduje odmiany rzeczownika "wiedza" w liczbie mnogiej, nie mogę tu pisać o „różnych typach wiedzy”, gdyż zakładałoby to istnienie jednej wiedzy, wbrew klarownym intencjom Haraway). Jak zaś podkreślała w podsumowaniu, tytułowe wiedze usytuowane „wymagają tego, żeby ich przedmiot przyjął postać aktora i sprawcy, a nie służył wyłącznie za ekran, obojętne tło czy gotowe do eksploatacji zasoby naturalne, posłuszny niewolnik tego mistrza, który likwiduje dialektykę poprzez wyjątkowy status własnej sprawczości jako źródła wiedzy «obiektywnej»" (s. 592). Podstawowy dogmat obiektywizmu i uniwersalizmu metod naukowych,

15 B. Latour An Inquiry into Modes of Existence: An Anthropology of the Moderns, Harvard University Press, Cambridge, MA 2013. w Puszczy Amazońskiej, przeł. K. Abriszewski, w: tegoż Nadzieja Pandory. Eseje o rzeczywistości wstudiach nad nauka [1999], Wydawnictwo Naukowe UMK, Toruń 2013, s. 55-112.

17 D. Haraway Situated Knowledges: The Science Question in Feminism and the Privilege in Partial Perspective , „Feminists Studies” 1988 No. 3, s. 575-599. 
wypracowany w połowie XVII wieku w dziedzinie nauk eksperymentalnych, a następnie przejmowany przez inne nauki, jeśli tylko chciały zasłużyć na to miano, to główny przeciwnik Haraway. Jak z przekonaniem twierdzi, tradycyjne kategorie filozoficzne większą wagę przywiązują do kwestii etycznych i politycznych niż epistemologicznych. To zaś przesądza o ich ideologicznym charakterze, niejawnym i dlatego bezkarnym. Co istotne, postulowane przez nią w Situated Knowledges „usytuowane i ucieleśnione wiedze", zdolne dzięki temu do ponoszenia odpowiedzialności za formułowane tezy i używane narzędzia poznawcze, należy odróżnić zarówno od wszelkich totalizujących wersji autorytatywnych Nauki, jak i od różnych jej ujęć relatywistycznych. Wiedza sytuowana wcale nie podważa prawdziwości własnych ustaleń. Ujawnia jedynie warunki epistemologiczne, w jakich zostały one poczynione i w jakich możliwa jest ich weryfikacja.

Także propozycje Haraway dziś zapewne wymagają częściowej weryfikacji. Wiedze lokalne uważała ona za usytuowane głównie w kobiecym ciele, co przeczy postulowanej w tym samym tekście-manifeście różnorodności stanowisk i perspektyw cząstkowych. Tymczasem praktyki kontrfaktualne pozwalają ulokować daną perspektywę nie tylko w określonym płcią biologiczną i kulturową ciele, lecz także w innych miejscach. Takich miejscach, które w danym momencie ułatwiają krytyczny stosunek do dominujących dyskursów, specyficznych dla nich krążących referencji, co pomaga dotrzeć do samych podstaw ich performatywności. Sens tego gestu lepiej ujawnia się w chwili, kiedy nazwę tych praktyk zapiszemy z literą "f" w nawiasie: kontr(f)aktualne. Jak klarownie widać, chodzi tu o wypadkową zajmowanej przez badacza pozycji oraz aktualnego horyzontu poznawczego i typowej dlań retoryki produkcji wiedzy. Znakomite pole do uprawiania takich praktyk oferują twory niejednorodne i hybrydyczne, tym razem wszakże powstające na pograniczu literatury i nauk ścisłych.

Przedstawiciele nauk ścisłych coraz częściej dostrzegają możliwość zaprzeczenia dawnej tezie C.P. Snowa o istnieniu dwóch odrębnych kultur, nie tylko wyrażając zgodę na współpracę przy powstawaniu filmów fabularnych i seriali telewizyjnych, ale także próbując swoich sił w literaturze. Zajmują się nie tylko literaturą fantastyczną i popularnonaukową, przynajmniej częściowo rezygnując z typowego dla danej specjalności, eksperckiego języka, żeby w przystępny i poglądowy sposób przedstawić trudne zagadnienia ${ }^{18}$. Coraz częściej sięgają także po różne formy powieściowe, zręcznie pastiszując istniejące gatunki i style czy przepisując dzie-

18 Tego, że robią to z powodzeniem, najlepiej dowodzi specjalizujący się w fizyce teoretycznej i kosmologii Stephen Hawking, którego Krótka historia czasu w 1988 roku przez wiele miesięcy otwierała listę bestsellerów w Stanach Zjednoczonych i Wielkiej Brytanii. 
ła $\mathrm{z}$ kanonu. Zrobiła tak niedawno w unowocześnionej wersji indyjskiego eposu Ramajana Joan Roughgarden ${ }^{19}$, amerykańska specjalistka od biologii ewolucyjnej i ekologii. Natomiast kilka lat wcześniej geolog James Lawrence Powell w 2084: An Oral History of the Great Warming połączył elementy ekologii z konwencjami literatury dokumentarnej ${ }^{20}$. Ustaleniom klimatologów i przewidywanym przez nich zmianom w drugiej połowie XXI wieku nadał on definitywną formę spełnionej przepowiedni, osadzając akcję w tytułowym 2084 roku, kiedy na Ziemi przetrwał zaledwie nikły procent liczby dzisiejszych mieszkańców. Kilkanaście fikcyjnych wywiadów, z odmiennych perspektywy referujących postępującą zagładę, miało w intencji Powella poprzez mockumentalną formę uświadomić wagę zagrożeń klimatycznych tym odbiorcom, którzy nie czytają alarmujących raportów ekologów i dziennikarzy. Nieco inaczej niż Powell postąpił ponad dekadę wcześniej w Turn Right at Orion Mitchell Begelman, astrofizyk z Uniwersytetu Colorado ${ }^{21}$. Jednak i on zdecydował się na formę literacką, żeby przystępnie przedstawić tę wysoce specjalistyczną wiedzę o wszechświecie, którą zwykle przekazuje studentom na wykładach.

Begelman sięgnął po rozwiązanie, którym posługiwali się już pisarze oświeceniowi, Jan Potocki zaś umieścił je nawet w tytule Ręhopisu znalezionego w Saragossie, dając tym samym do zrozumienia czytelnikom, że jego rola ograniczyła się do wydania cudzej relacji z autentycznych zdarzeń. Dość jednak przypomnieć Pamiętnik znaleziony w wannie Stanisława Lema, by zdać sobie sprawę, że po upływie dwóch wieków zmieniła się znacznie funkcja dawnego rozwiązania uwiarygodniającego. To, co kiedyś służyło za rękojmię autentyczności, dziś stanowi raczej sygnał przynależności do świata literatury. O taki też bodaj sygnał chodziło Begelmanowi, kiedy utrzymaną w pierwszej osobie relację z podróży w kosmosie dzisiejszego astrofizyka, który chce wykorzystać szansę na obserwację gołym okiem, zdobycie doświadczeń z pierwszej ręki i weryfikację teoretycznych spekulacji, opatrzył przedmową od znalazcy i tłumacza. Dzieląca je przepaść sześćdziesięciu milionów lat świetlnych nadała naukowemu wykładowi pożądany pozór fantastycznonaukowej fikcji. Już jednak zakończenie Turn Left at Orion nie stara się nawet o podtrzymanie tego wrażenia. Słowniczek wyrażeń astrofizycznych i indeks rzeczowy należą przecież do typowego wyposażenia prac naukowych. Co istotne, napięcie między fikcyjną przedmową od tłumacza a tradycyjnie akademickim zakończe-

J. Roughgarden Ram-2050: A Ramayana Epic for the Future, Kauai Institute 2015.

J.L. Powell 2084: An Oral History of the Great Warming [2011], http://www.amazon.com/2084-History-Warming-Kindle-Single-ebook/dp/Boo4TAD8Go (23.08.2016).

21 M. Begelman Turn Right at Orion. Travel through the Cosmos, Basic Books, New York 2000. 
niem cechuje też inne poziomy tej książki. Z jednej strony astrofizyk odbywa pikarejską podróż po przestrzeniach międzygwiezdnych w formie znanego dobrze graczom komputerowym "questu", poszukując rozwiązania ostatecznej tajemnicy wszechświata, zbierając w nagrodę doświadczenia i dzięki nim weryfikując swoją wiedzę teoretyczną. Z drugiej strony jego życie ogranicza się niemal wyłącznie do spekulacji na temat ciał kosmicznych i rozwoju kosmosu, zaś zarówno materialność statku, jak i jego własnego ciała ma znaczenie wyłącznie wówczas, kiedy okazuje się niezbędna z uwagi na retoryczną siłę intelektualnego wywodu. Trudno uznać to jedynie za efekt braku pisarskiego talentu autora. To raczej świadomy zabieg konstrukcyjny o zamierzonych celach poznawczych. Uniemożliwia on wręcz swobodne zanurzenie się w świecie przedstawionym fantastyki naukowej, który zamiast trzech spodziewanych wymiarów ma tu jedynie dwa, ujawniając swój charakter teatralnych dekoracji. Begelman odsłonił dzięki temu zarówno dalece umowny charakter fikcji artystycznej, jak i same podstawy fikcyjności naukowego obiektywizmu i wiedzy doświadczalnej, wiedzy z pierwszej ręki.

Turn Left at Orion Begelmana dobrze oddaje istotę przemian w praktykach kontrfaktycznych ostatnich dekad. Jak jednak twierdzi francuski filozof Guillaume Pigeard de Gurbert, autor wydanej w tym roku pracy Le spectre du possible, zachodzące na naszych oczach przemiany nie tylko obejmują pogranicze fikcji i nauk, lecz także biorą udział w grze o znacznie wyższą stawkę ${ }^{22}$. Wzrastające zainteresowanie kontrfaktualnością to dla niego najlepszy dowód, że współczesna kultura staje się - jak niedawno zręcznie ujął to Ryszard Nycz - z rzeczownika czasownikiem, ujawniając swoją źródłową performatywnośćc ${ }^{23}$. On sam proponuje nie tylko definicję tytułowego „possible”, lecz również nową historię filozofii, która wychodzi od koncepcji „krisis” Parmenidesa. W tej perspektywie Pigeard de Gurbert odczytuje poglądy myślicieli, którzy stworzyli same podwaliny naszej kultury. Jak mi się wydaje, zarówno zakres przemian, jak i ich wyższa stawka często nam umykają, kiedy zajmują nas głównie definicje i partykularne skutki kolejnych - czy też zachodzących równoległe w różnych naukach - zwrotów, dokonujących zwykle lokalnych modyfikacji tego, co Latour nazywa właściwym dla danej dyscypliny krążeniem referencji.Zaś praktyki kontrfaktyczne, uprawiane na pograniczu literatury i różnych nauk, owocujące niejednorodnymi, mockumentarnymi formami, znakomicie o tej wyższej stawce przypominają, każda w swoisty dla siebie sposób materializując wiedze praktyczne i praktykowane.

G. Pigeard de Gurbert Le spectre du possible, Kimé, Paris 2016.

R. Nycz Kultura jako czasownik, wykład podczas Festiwalu Kopernika, Kraków, 11.05.2015. 


\section{Abstract}

\section{Małgorzata Sugiera}

JAGIELLONIAN UNIVERSITY (CRACOW)

Counter-Factual Practices in Academic and Fictional Narratives

This article deals with counter-factual practices in history and the historical novel (whose production has increased in the last few years, and which presents alternative versions of the past), as well as in areas where the humanities and the natural or exact sciences intersect with works of literary fiction that incorporate elements of science fiction. Based on a selection of mockumentary works by respected academics from various disciplines, Sugiera demonstrates the essential function that these practices have in undermining the objectivity of academic discourses and in highlighting the fact that knowledge is situated.

\section{Keywords}

counter-factuality, alternative histories, mockumentary works, situated knowledge 